\title{
Implementasi Manajemen Pembelajaran Saintifik di Institut Agama Hindu Negeri Tampung Penyang Palangka Raya
}

\author{
I Putu Widyanto \\ Institut Agama Hindu Negeri Tampung Penyang Palangka Raya \\ putuwidyanto@yahoo.co.id
}

\begin{abstract}
Riwayat Jurnal
Artikel diterima: 18 April 2019

Artikel direvisi: 25 Juni 2019

Artikel disetujui: 25 Juni 2019
\end{abstract}

\begin{tabular}{|c|c|}
\hline $\begin{array}{l}\text { Kata Kunci: } \\
\text { Manajemen pembelajaran } \\
\text { Pembelajaran saintifik }\end{array}$ & $\begin{array}{l}\text { Abstrak } \\
\text { Penelitian ini untuk mendeskripsikan implementasi manajemen } \\
\text { pembelajaran pada mata kuliah yang menggunakan pembelajaran } \\
\text { saintifik di IAHN-TP Palangka Raya. Pendekatan penelitian ini } \\
\text { menggunakan pendekatan kualitatif dengan menggunakan desain } \\
\text { deskriptif. Penelitian dilaksanakan di Institut Agama Hindu } \\
\text { Negeri Tampung Penyang Palangka Raya Indonesia. Peneliti } \\
\text { mengumpulkan berbagai informasi dengan wawancara tak } \\
\text { berstruktur dan observasi tersamar. Analisis data hasil } \\
\text { wawancara dengan model interaktif analisis model dari Miles } \\
\text { dan Huberman serta analisis data hasil observasi dilakukan } \\
\text { dengan metode checklist. Hasil penelitian menunjukan tahapan } \\
\text { manajemen pembelajaran saintifik terdiri dari tahapan } \\
\text { perencanaan pembelajaran, pelaksanaan pembelajaran dan } \\
\text { pengawasan pembelajaran. }\end{array}$ \\
\hline $\begin{array}{l}\text { Keyword: } \\
\text { Learning management } \\
\text { Scientific learning }\end{array}$ & $\begin{array}{l}\text { Abstract } \\
\text { This study is to describe the implementation of learning } \\
\text { management in subjects that use scientific learning at the IAHN- } \\
\text { TP Palangka Raya. This research approach uses a qualitative } \\
\text { approach using descriptive design. The research was conducted } \\
\text { in Institut Agama Hindu Negeri Tampung Penyang Palangka } \\
\text { Raya Indonesia. The researcher collected various information by } \\
\text { structured interviews and disguised observations. Analysis of } \\
\text { interview data with an interactive model analysis model from } \\
\text { Miles and Huberman and analysis of data from observations } \\
\text { carried out by the checklist method. The results showed the } \\
\text { stages of scientific learning management consisted of stages of } \\
\text { learning planning, implementation of learning and supervision of } \\
\text { learning. }\end{array}$ \\
\hline
\end{tabular}




\section{Pendahuluan}

Pembelajaran merupakan proses interaksi peserta didik dengan pendidik dan sumber belajar pada suatu lingkungan belajar (Suyanto \& Jihad, 2013:275), baik interaksi secara langsung maupun tidak langsung dengan menggunakan media (Rusman, 2017:84), dimana interaksi yang berlangsung melibatkan peran aktif peserta didik dalam kegiatan pembelajaran sehingga peserta didik tidak terpaku pada penjelasan pendiidk (Sari, 2015:23). Pembelajaran adalah suatu proses yang dilakukan oleh individu untuk memperolah suatu perubahan dalam perilaku yang baru secara keseluruhan sebagai hasil interaksi antara dirinya dengan lingkungannya (Saifudin, 2014:3), perubahan tersebut bukan hanya terjadi selama proses perolehan ilmu dan pengetahuan, penguasaan kemahiran dan tabiat, juga pembentukan sikap dan kepercayaan pada peserta didik (Suardi, 2015:7).

Pembelajaran yang melibatkan peserta didik secara aktif berdampak memberikan pengalaman belajar lebih banyak kepada peserta didik (Sidek \& Yunus, 2012:135-143). Salah satu pendekatan pembelajaran yang melibatkan peserta didik secara aktif adalah pendekatan pembelajaran saintifik, dimana menekankan pada proses pencarian pengetahuan dari pada transfer pengetahuan, peserta didik dipandang sebagai subjek belajar yang perlu dilibatkan secara aktif dalam proses pembelajaran (Suhartati, 2016), melalui kegiatan mengkonstruksi konsep meliputi mengamati, menanya, mengumpulkan informasi/data, mengasosiasi/mengolah informasi dan mengomunikasikan (Hosnan, 2014:39).

Pembelajaran dengan pendekatan saintifik akan bermuara pada peningkatan kreativitas peserta didik dalam memecahkan persoalan yang dihadapi selama proses pembelajaran (Atsnan \& Gazali, 2013:429-436), sehingga ada beberapa metode pembelajaran berbasis pendekatan saintifik yang tepat untuk digunakan antara lain metode pembelajaran inkuiri; metode pembelajaran discovery; metode pembelajaran berbasis masalah dan metode pembelajaran berbasis proyek (Abidin, 2016:149-179).

Kegiatan pembelajaran direncanakan untuk memberikan pengalaman belajar yang melibatkan proses mental dan fisik melalui interaksi aktif antar peserta didik dengan pendidik, lingkungan dan sumber belajar lainnya dalam rangka mencapaian capaian pembelajaran (Rusman, 2017:85). Pembelajaran yang melibatkan peserta didik secara aktif akan berdampak memberikan pengalaman belajar lebih banyak (Sidek \& Yunus, 2012:135143), serta tercapainya tujuan pembelajaran untuk memenuhi kriteria minimal kemampuan lulusan yang mencakup ranah sikap, pengetahuan dan keterampilan yang dapat terlaksana 
secara efektif bila didukung manajemen (Manullang, 2014:210). Manajemen merupakan komponen integral dan tidak dapat dipisahkan dari proses pembelajaran secara keseluruhan, karena tanpa manajemen tidak mungkin capaian pembelajaran dapat diwujudkan secara optimal, efektif dan efisien (Rukayah \& Ismanto, 2016:178).

Manajemen pembelajaran merupakan pengelolaan fungsi perencanaan, fungsi mengorganisasikan, fungsi pelaksanaan dan fungsi pengawasan (Terry, 2012:115), yang berhubungan dengan proses pembelajaran (Hamalik, 1995:68), untuk mencapai tujuan pembelajaran secara efektif dan efisien (Majid, 2005:17). Kemampuan pengelolaan proses pembelajaran merupakan kemampuan yang wajib dimiliki pendidik agar proses pembelajaran berjalan efektif, karena pembelajaran merupakan aktivitas tenaga pendidik mengelola pembelajaran untuk menciptakan kondisi yang memungkinkan proses belajar peserta didik berlangsung optimal, pendidik bertugas membantu peserta didik dengan memanipulasi lingkungan sehingga peserta didik dapat belajar dengan mudah (Gora, Winastwan, \& Sunarto, 2010:1), kondisi tersebut membuat peneliti tertarik untuk melakukan penelitian terhadap implementasi manajemen pembelajaran pada pembelajaran saintifik di Institut Agama Hindu Negeri Tampung Penyang (IAHN-TP) Palangka Raya.

\section{Metode}

Penelitian ini menggunakan pendekatan kualitatif dengan menggunakan desain deskriptif. Penelitian dilaksanakan di Institut Agama Hindu Negeri Tampung Penyang (IAHN-TP) Palangka Raya Indonesia. Peneliti mengumpulkan berbagai informasi terhadap dosen yang melaksanakan manajemen pembelajaran pada pembelajaran dengan pendekatan saintifik, selanjutnya peneliti akan menganalisis implementasi manajemen pembelajaran tersebut dengan tujuan untuk mendapatkan deskripsi dari implementasi manajemen pembelajaran pada pembelajaran dengan pendekatan saintifik di perguruan tinggi. Sumber data penelitian pertama berasal dari informan, yaitu dosen sebagai pendidik untuk mendapatkan data tentang implementasi manajemen pembelajaran pada pembelajaran dengan pendekatan saintifik. Sumber data penelitian kedua dari proses observasi terhadap pelaksanaan pembelajaran di kelas, untuk mendapatkan gambaran dari implementasi manajemen pembelajaran pada pembelajaran dengan pendekatan saintifik.

Teknik pengumpulan data penelitian pertama dengan wawancara tak berstruktur pada pendidik yang melaksanakan manajemen pembelajaran pada pembelajaran dengan pendekatan saintifik. Sedangkan untuk teknik sampling yang digunakan menggunakan teknik 
sampling purposive sampling pada pendidik karena mereka dianggap paling memahami tentang apa yang peneliti harapkan. Teknik pengumpulan data penelitian kedua dengan observasi tersamar untuk mendapatkan gambaran dari implementasi manajemen pembelajaran pada pembelajaran dengan pendekatan saintifik.

Untuk menguji keabsahan data berupa data hasil wawancara dan observasi peneliti akan menggunakan teknik triangulasi sumber. Untuk uji validitas instrumen penelitian berupa instrumen wawancara dan instrumen observasi, peneliti terlebih dahulu menentukan teori atau konsep apa yang akan digunakan sebagai acuan wawancara dan observasi. Konsep atau teori itu kemudian diturunkan menjadi beberapa indikator yang dipakai untuk menjadi tolok ukur operasional konsep tersebut. Sedangkan untuk uji reliabilitas pada instrumen wawancara lebih menekankan kepada keajegan hasil jawaban yang dimunculkan oleh narasumber. Reliabilitas pada instrumen observasi berdasarkan aturan/pedoman yang dibuat peneliti dan ditaati saat observasi.

Teknik analisis data dari sumber data informan hasil wawancara pendidik menggunakan analisis data lapangan model interactive analysis models dari Miles dan Huberman, dimana tahapan pengumpulan data, penyajian data, reduksi data dan pengambilan kesimpulan dilakukan bersamaan dengan proses pengumpulan data serta saling berinteraksi. Sedangkan analisis data hasil observasi dilakukan dengan metode checklist.

\section{Hasil}

Penelitian ini meneliti persepsi dosen yang mengampu mata kuliah pendidikan pancasila pada program studi pendidikan agama Hindu di IAHN-TP Palangka Raya semester ganjil 2018/2019 dengan melaksanakan proses pembelajaran menggunakan prinsip-prinsip manajemen pembelajaran dengan pendekatan saintifik. Temuan terhadap persepsi tersebut dijelaskan sebagai berikut :

\section{Perencanaan Pembelajaran}

Berdasarkan hasil wawancara terhadap dosen yang mengampu mata kuliah pendidikan pancasila ditemukan berbagai aktifitas selama proses perencanaan tersebut. Aktifitas tersebut antara lain: Merumuskan rencana pembelajaran semester (RPS); Menyusun perangkat pembelajaran berupa buku pedoman pembelajaran yang digunakan oleh pendidik dan buku pedoman yang digunakan mahasiswa dan kontrak perkuliahan; Menyerahkan RPS dan perangkat pembelajaran berupa pedoman dan kontrak perkuliahan kepada program studi untuk dievaluasi apakah sudah sesuai dengan kurikulum dan silabus yang ada. 


\section{Pelaksanaan Pembelajaran}

Berdasarkan hasil wawancara terhadap dosen yang mengampu mata kuliah pendidikan pancasila ditemukan berbagai aktifitas selama proses pelaksanaan tersebut. Aktifitas tersebut antara lain: Melaksanakan kegiatan awal pembelajaran yang dimulai dari dosen memberi salam dan mengajak mahasiswa berdoa; Mengabsen mahasiswa, serta menanyakan keadaannya; Menyampaikan isi dari silabus, RPS, kontrak perkuliahan dan pedoman pembelajaran dengan tujuan agar mahasiswa dapat memahami tujuan dari proses pembelajaran, pendekatan, metode dan penilaian pembelajaran selama satu semester yang akan dijalani; Memberikan gambaran tentang pentingnya memahami materi yang akan dibahas sekaligus memberikan gambaran secara umum materi yang akan dipelajari, serta menyampaikan capian pembelajaran yang ingin dicapai; Memberikan apersepsi; Membentuk kelompok belajar; Memberikan tugas mandiri sebelum pembelajaran dimulai dengan tema materi pertemuan selanjutnya; Melaksanakan kegiatan inti pembelajaran saintifik dengan metode pembelajara berbasis masalah dengan tahapan sebagai berikut ; mengamati, menanya, mengumpulkan informasi, mengolah informasi, mengkomunikasikan dan menciptakan solusi pemecahan masalah; Melaksanakan kegiatan penutup pembelajaran dimulai dengan dosen bersama mahasiswa menyimpulkan hasil pembahasan dan pendidik memberikan penguatan; Melakukan refleksi terhadap hasil diskusi; Memberikan tugas mandiri berstruktur untuk pertemuan berikutnya; Diakhiri dengan doa.

\section{Pengawasan Pembelajaran}

Berdasarkan hasil wawancara terhadap dosen yang mengampu mata kuliah pendidikan pancasila semester ganjil 2018/2019 ditemukan berbagai aktifitas selama proses pengawasan tersebut. Aktifitas tersebut terdiri dari: Pengawasan internal terdiri aktifitas pemantuan, supervisi, evaluasi, pelaporan dan tindak lanjut; Pengawasan eksternal terdiri aktifitas pemantuan, supervisi, evaluasi, pelaporan dan tindak lanjut.

\section{Pembahasan}

\section{Perencanaan Pembelajaran}

Perencanaan pembelajaran merupakan pengambilan keputusan atas berbagai pilihan yang akan dilaksanakan untuk mencapai tujuan yang telah ditentukan, dimana perencanaan mengandung rangkaian putusan dan penjelasan dari tujuan, penentuan kebijakan, penentuan 
program, penentuan metode dan prosedur tertentu dan penentuan kegiatan yang akan dilaksanakan (Suryapermana, 2017:183). Aktifitas pertama yang dilakukan dosen pada tahap ini adalah dosen akan merumuskan RPS. Merumuskan RPS selain berpedoman pada kurikulum dan silabus pendidik juga memperhatikan aturan-aturan yang terdapat pada Permenristekdikti No. 44 Tahun 2015 tentang standar nasional pendidikan tinggi, antara lain;

\section{Capaian Pembelajaran Lulusan.}

Proses pembelajaran yang baik adalah proses pembelajaran yang mampu memberikan pengalaman belajar secara bermakna kepada mahasiswa untuk membuka keunikan potensi dirinya dalam menginternalisasikan pengetahuan, keterampilan dan sikap (Sutrisno \& Suyadi, 2016:110), berupa kegiatan memberikan pengalaman belajar yang melibatkan proses mental dan fisik melalui interaksi antar mahasiswa, mahasiswa dengan dosen, lingkungan dan sumber belajar lainnya dalam rangka mencapaian capaian pembelajaran berupa aspek sikap, pengetahuan dan keterampilan (Rusman, 2017:85).

\section{Karakteristik Pembelajaran}

Pembelajaran yang melibatkan mahasiswa secara aktif berdampak memberikan pengalaman belajar lebih banyak kepada mahasiswa (Sidek \& Yunus, 2012:135-143). Salah satu pendekatan pembelajaran yang melibatkan mahasiswa secara aktif adalah pendekatan pembelajaran saintifik, pembelajaran saintifik menekankan pada proses pencarian pengetahuan dari pada transfer pengetahuan, mahasiswa dipandang sebagai subjek belajar yang perlu dilibatkan secara aktif dalam proses pembelajaran (Suhartati, 2016).

\section{Metode Pembelajaran.}

Penggunaan metode yang tidak sesuai dengan capaian pembelajaran akan menjadi kendala dalam mencapai tujuan yang telah dirumuskan karena setiap metode pembelajaran memiliki keunggulannya, oleh sebab itu pemahaman dosen dalam memilih metode pembelajaran sangat penting sebelum memutuskan metode mana yang akan dipakai selain pertimbangan capaian pembelajaran yang akan dituju (Samiudin, 2016:119), karena tinggi dan rendahnya hasil belajar yang diperoleh mahasiswa tergantung salah satunya dari metode pembelajaran yang digunakan oleh dosen (Kartiani, 2015:213). Kemampuan berpikir kritis dan kreatif mahasiswa dapat dilatih dengan pembelajaran yang menuntut mahasiswa untuk melakukan eksplorasi, inkuiri, penemuan dan memecahkan masalah sehingga salah satu model pembelajaran yang dapat diasumsikan mampu meningkatkan kemampuan berpikir kritis dan kreatif mahasiswa yaitu model pembelajaran berbasis masalah (Sunaryo, 2014:42). 


\section{Prinsip Penilaian}

Penilaian hendaknya berorientasi pada ketercapaian pembelajaran, bukan vonis terhadap kesalahan (Sutrisno \& Suyadi, 2016:162). Penilaian otentik adalah pengukuran yang bermakna secara signifikan atas hasil belajar mahasiswa untuk ranah sikap, keterampilan, dan pengetahuan, penilaian otentik memiliki relevansi kuat terhadap pendekatan ilmiah dalam pembelajaran yang mampu menggambarkan peningkatan hasil belajar mahasiswa, baik dalam rangka mengobservasi, menalar, mencoba, membangun jejaring dan yang lainnya (Putra, 2015:208).

Kedua dosen menyusun perangkat pembelajaran berupa buku pedoman pembelajaran yang digunakan oleh pendidik dan buku pedoman yang digunakan mahasiswa serta kontrak perkuliahan. Untuk mempermudah, pendidik dan mahasiswa dalam pelaksanaan pembelajaran saintifik dibutuhkan sebuah pedoman yang merupakan sebuah dokumen yang berisi prinsip dasar serta merupakan dokumen induk yang memayungi dan menjadi acuan bagi pengguna (Soemohadiwidjojo, 2014:87).

Ketiga dosen menyerahkan RPS dan perangkat pembelajaran berupa pedoman kepada program studi dan kontrak perkuliahan untuk dievaluasi apakah sudah sesuai dengan kurikulum dan silabus yang ada. Evaluasi berkaitan dengan proses memberikan penilaian berdasarkan kriteria dan standar yang sudah ada (Gunawan \& Palupi, 2012:28), yang meliputi pemeriksaan apakah semua berjalan sesuai rencana yang dibuat, instruksi yang dikeluarkan dan prinsip yang ditetapkan (Sagala, 2011:65).

Perencanaan pembelajaran sangat penting karena sebagai alat pemandu bagi pendidik dalam melaksanakan proses pembelajaran, oleh sebab itu perencanaan haruslah lengkap, sistematis mudah diaplikasikan namun fleksibel dan akuntabel (Abidin, 2016:287), serta dapat menjadi pedoman dan standar dalam usaha pencapaian tujuan (Rayuni, 2010:77).

\section{Pelaksanaan Pembelajaran}

Pelaksanaan pembelajaran merupakan implementasi rencana program pembelajaran yang telah dibuat oleh dosen pada tahap perencanaan pembelajaran (Novalita, 2014:59).

Kegiatan pertama yang dilakukan dosen pada tahap ini adalah dosen memberi salam dan mengajak mahasiswa berdoa. Kompetensi sikap dibagi menjadi dua yaitu sikap spiritual dan sikap sosial, jika kompetensi sikap spiritual dan sosial tersebut tidak diajarkan, kompetensi tersebut harus terimplementasikan dalam proses pembelajaran melalui pembiasaan dan keteladanan yang ditunjukkan oleh mahasiswa dalam keseharian melalui dampak pengiring dari pembelajaran (Setiawan, 2017:44). 
Kedua, dosen mengabsen mahasiswa, serta menanyakan keadaannya. Taat hukum dan disiplin dalam kehidupan bermasyarakat dan bernegara adalah salah satu unsur sikap yang wajib dimiliki mahasiswa, yang ditetapkan di dalam Permenristekdikti No 44 Tahun 2015 tentang SNPT. Pengembangan sikap ini dilakukan oleh dosen, melalui kegiatan mengecek tingkat kehadiran mahasiswa, sehingga proses dalam pembelajaran tersebut bertujuan untuk mengembangkan perilaku yang terkait dengan sikap yang termuat capaian pembelajaran (Asmarawati, Riyadi, \& Sujadi, 2016:59).

Ketiga dosen akan menyampaikan isi dari silabus, RPS dan kontrak perkuliahan dengan tujuan agar mahasiswa dapat memahami tujuan dari proses pembelajaran, pendekatan, metode dan penilaian pembelajaran selama satu semester yang akan dijalani. Penyampaian tujuan pembelajaran sebelum memulai pembelajaran, merupakan salah satu strategi yang dapat memotivasi mahasiswa untuk berusaha mencapai tujuan pembelajaran yang diinginkan (Barlian, 2013:244).

Keempat, dosen memberikan gambaran tentang pentingnya memahami materi yang akan dibahas sekaligus memberikan gambaran secara umum materi yang akan dipelajari, serta menyampaikan capian pembelajaran yang ingin dicapai. Penyampaian capian pembelajaran sebelum memulai pembelajaran merupakan kegiatan awal yang harus dilakukan dosen (Awaludin, Mallo, \& Lefrida, 2016:81), dengan tujuan dapat membuat mahasiswa paham kearah mana ia ingin dibawa, sehingga pemahaman mahasiswa terhadap tujuan pembelajaran dapat menumbuhkan minat mahasiswa untuk belajar yang pada gilirannya dapat meningkatkan motivasi belajar mereka (Suprihatin, 2015:78).

Kelima, dosen memberikan apersepsi untuk mendorong rasa ingin tahu dan berpikir kritis, dengan tanya jawab, mahasiswa diajak mengingat kembali tentang gambaran materi secara umum berdasarkan tugas mandiri yang telah diberikan. Apersepsi memuat kegiatan pengenalan dan review yang merupakan bagian pertama dari proses pembelajaran dan dirancang untuk menarik perhatian mahasiswa, mendorong mahasiswa masuk ke dalam pelajaran, mengingatkan mahasiswa terhadap materi yang telah dipelajari sebelumnya, dan memfokuskan perhatian mahasiswa pada pembelajaran (Palupi, Yuwono, \& Muksar, 2017:10),

Keenam, dosen membentuk kelompok belajar. Metode pembelajaran yang menggunakan kelompok belajar diharapkan dapat meningkatkan kemampuan mahasiswa sehingga mahasiswa dalam kelompok kecil dapat bekerja sebagai suatu tim untuk 
menyelesaikan sebuah masalah, menyelesaikan suatu tugas, atau mengerjakan sesuatu untuk tujuan bersama lainnya (Hadi \& Noor, 2013:61). Kegiatan ini memiliki dua fungsi sekaligus yaitu melakukan bimbingan belajar dan sosial, karena disamping dapat belajar secara individu mahasiswa juga dapat belajar dengan sistem kelompok, selain itu anak akan memiliki kesempatan lebih besar dan intens untuk meningkatkan interaksi sosialnya, selain itu dalam kaitan dengan pengertian kelompok, kita dapat melihat adanya interaksi, pengaruh, serta tujuan bersama (Lutfiyanti, 2013:339).

Ketujuh, dosen memberikan tugas mandiri sebelum pembelajaran dimulai dengan tema materi pertemuan selanjutnya. Tugas diberikan agar mahasiswa dapat mengumpulkan informasi terlebih dahulu dan dapat memahami materi yang akan dipelajari nantinya, karena mahasiswa dapat belajar dengan baik dan memahami konsep melalui peran aktifnya dalam mengumpulkan informasi secara mandiri (Bruner dalam Dahar, 2011:79).

Kedelapan dosen melaksanakan kegiatan pembelajaran inti dengan tahapan sebagai berikut: Mengamati, mahasiswa diberikan permasalahan dalam bentuk tertulis atau berupa vidio, berisi fenomena yang membutuhkan penjelasan. Mengamati adalah melihat fakta dengan seksama terhadap objek yang diamatinya (Mulyana dkk, 2008:46). Proses mengamati digunakan untuk melihat dan mengamati perubahan fenomena sosial yang tumbuh dan berkembang yang kemudian dapat dilakukan perubahan atas penilaian tersebut (Andayani, 2015:388). Menanya, mahasiswa membuat pertanyaan-pertanyaan berdasarkan hasil pengamatan dan terhadap istilah atau pernyataan yang dianggap penting. Menanya merupakan kegiatan kedua setelah mengamati objek pengamatan, dari pengamatan tersebut diharapkan muncul sejumlah pertanyaan/persoalan yang akan dijadikan bahan diskusi. Sikap kritis mahasiswa harus didorong untuk bisa memunculkan beragam pertanyaan (Kosasih, 2014:75). Mengumpulkan informasi, dari pertanyaan yang sudah disusun, mahasiswa dapat mengumpulkan berbagai informasi untuk memperoleh jawaban dari pertanyaan yang ada. Mengumpulkan informasi merupakan kegiatan pembelajaran untuk mengumpulkan data yang akan digunakan untuk menjawab pertanyaan yang telah dikumpulkan, kegiatan pengumpulan informasi berupa eksperimen, membaca buku maupun sumber lain, mengamati objek/kejadian/aktivitas dan wawancara dengan narasumber (Yulaikah , 2016:22). Pada tahapan mengumpulkan informasi dosen dapat memberikan masukan dalam forum diskusi melalui aplikasi whatsapp terhadap proses pengumpulan data yang dilakukan mahasiswa dan mahasiswa pun dapat meminta masukan dosen terhadap data-data yang sudah didapat (Widyanto, Slamet, \& Prihatin, 2018:243). Mengolah Informasi, pada tahap ini mahasiswa 
membawa berbagai informasi yang didapat kedalam proses diskusi secara kelompok dan mahasiswa memberikan kesimpulan secara bersama terhadap pertanyaan dan permasalahan dan membuat laporan untuk di komunikasikan dengan kelompok lain dalam proses diskusi bersama. Setelah semua informasi yang dibutuhkan untuk menjawab pertanyaan telah didapat tahap selanjutnya adalah tahapan mengolah informasi untuk menjadi sebuah kesimpulan dari pertanyaan yang ada. Mengolah informasi merupakan kegiatan menganalisis data yang sudah dikumpulkan dalam bentuk membuat kategori, mengasosiasi atau menghubungkan fenomena/informasi yang terkait dalam rangka menemukan suatu pola, dan menyimpulkannya (Widiawati, Nurani, \& Patriasih, 2015:42), dengan proses berpikir yang logis dan sistematis atas fakta empiris yang dapat diobservasi (Rusman, 2017:430). Mengkomunikasikan, pada tahap ini mahasiswa menyampikan hasil kegiatannya dalam bentuk presentasi dihadapan kelompok lain dan mahasiswa dari kelompok lain dapat memberikan komentar terhadap presentasi yang ditampilkan (proses diskusi). Setelah mahasiswa menyelesaikan tahapan mengolah informasi dan mendapatkan kesimpulan dari berbagai pertanyaan yang ada selanjutnya, mahasiswa dapat mengkomunikasikan hasil kegiatannya kepada pihak lainnya. Mengkomunikasi merupakan kemampuan menyampaikan hasil kegiatan yang telah dilaksanakan baik secara lisan maupun tulisan (Rusman, 2017:435), dalam hal ini mahasiswa harus mampu menulis dan berbicara secara komunikatif dan efektif (Abidin, 2016:141).

Kesembilan dosen melaksanakan kegiatan penutup pembelajaran dimulai dengan dosen bersama mahasiswa menyimpulkan hasil pembahasan dan pendidik memberikan penguatan. Pembelajaran dengan kondisi kelas aktif merupakan proses kegiatan belajar mengajar dimana mahasiswa terlibat secara intelektual dan emosional sehingga mahasiswa tersebut dapat berperan dan berpartisipasi aktif dalam kegiatan belajar mengajar (Hosnan, 2014:208), kondisi tersebut hanya dapat terwujud dengan pendidik memberikan kesempatan lebih banyak kepada mahasiswa untuk aktif di kelas.

Kesepuluh dosen dan mahasiswa melakukan refleksi terhadap hasil diskusi. Refleksi dilakukan untuk menganalisis hasil tindakan agar dapat memperbaiki tindakan berikutnya (Sulistyowati, 2016:186). Refleksi dilakukan untuk melakukan penilaian terhadap proses yang terjadi dan segala hal yang berkaitan dengan tindakan yang dilakukan, serta dilakukan dengan cara kolaboratif yaitu adanya diskusi tentang berbagai masalah yang muncul di kelas sehingga ditemukan strategi pemecahan masalah untuk perbaikan tindakan yang harus dilakukan bagi siklus berikutnya (Isnaniah, 2017:86). 
Kesebelas dosen memberikan tugas mandiri berstruktur untuk pertemuan berikutnya.

Pencarian pengetahuan secara aktif oleh mahasiswa dengan sendirinya memberikan hasil yang lebih baik, berusaha sendiri mencari pemecahan masalah serta didukung oleh pengetahuan yang menyertainya dan informasi baru yang didapat untuk menghasilkan pengetahuan yang benar-benar bermakna (Rusman, 2017:349).

Keduabelas diakhiri dengan doa. Pembiasaan adalah salah satu metode pengajaran yang paling efektif, khususnya dalam pembinaan sikap, cara tersebut secara umum dilakukan dengan pembiasaaan dan teladan, untuk itu ada beberapa strategi yang dapat dilakukan oleh para pendidik, di antaranya melalui memberikan contoh (teladan), membiasakan hal-hal yang baik, sehingga mahasiswa terbiasa mengucapkan salam karena pendidik sebagai figurnya selalu mengajak dan memberi contoh kepada mahasiswa tersebut demikian pula kebiasaan lainnya (Zuhri, 2013:116).

\section{Pengawasan Pembelajaran}

Pengawasan adalah kegiatan penilaian dan melakukan perbaikan terhadap aktivitas pembelajaran dengan harapan bahwa tujuan dan rancangan yang dibuat terlaksana (Kurniadin \& Machali, 2012:132). Pengawasan proses pembelajaran dilakukan melalui kegiatan pemantauan, supervisi, evaluasi, pelaporan, serta tindak lanjut secara berkala dan berkelanjutan (S, Usman, \& Niswanto, 2017:B155), yang dilakukan secara internal maupun secara eksternal (Ikhwan, 2016:130). Pengawasan internal merupakan suatu penilaian yang objektif dan sistematis oleh pendidik, yang menekankan pada pemberian bantuan kepada mahasiswa dalam mengidentifikasikan sekaligus mendorong perbaikan (Husman, 2008:537).

\section{Pemantauan pembelajaran}

Pemantauan adalah kegiatan mengamati perkembangan pelaksanaan proses pembelajaran, mengidentifikasi serta mengantisipasi permasalahan yang timbul atau akan timbul (Mulyono \& Yumari, 2017:15), sehingga dapat dilakukan tindakan koreksi untuk penyempurnaan selanjutnya (Triwiyanto, 2015:68).

\section{Supervisi pembelajaran}

Supervisi pembelajaran adalah segenap bantuan yang diberikan oleh pendidik kepada mahasiswa dalam mengembangkan situasi belajar mengajar (Triwiyanto, 2015:71), melalui kegiatan membimbing kegiatan pembelajaran (Mukhtar \& Iskandar, 2013:44), dalam rangka melakukan perbaikan pembelajaran yang tujuan akhirnya adalah peningkatan kualitas pembelajaran dan prestasi belajar mahasiswa (Widodo, 2007:296). 


\section{Evaluasi pembelajaran}

Ruang lingkup kegiatan evaluasi pembelajaran adalah evaluasi hasil belajar dan evaluasi program pembelajaran. Evaluasi program pembelajaran adalah kegiatan mengevaluasi hal-hal yang dilakukan dalam proses pembelajaran meliputi perencanaan, pelaksanaan dan proses penilaian serta dampaknya terhadap mahasiswa. Evaluasi ini dilakukan dengan tujuan dapat memperbaiki kekurangan dalam pembelajaran, dan dapat dijadikan dasar untuk proses pembelajarannya selanjutnya (Lukum, 2015:28). Sedangkan evaluasi hasil belajar adalah kegiatan penilaian penguasaan mahasiswa terhadap tujuan pembelajaran yang sudah ditetapkan sebelum berlangsungnya kegiatan belajar mengajar, yang tujuan untuk mengetahui sejauhmana penguasaan mahasiswa terhadap kompetensi yang harus dikuasai sebagaimana yang telah dirumuskan pada profil kompetensi lulusan (Purnomo \& Munadi, 2005:265).

\section{Pelaporan Pembelajaran}

Laporan hasil belajar merupakan ringkasan hasil penelitian terhadap seluruh aktivitas pembelajaran yang dilakukan mahasiswa dalam kurun waktu tertentu (Rusman, 2017:475). Laporan evaluasi program pembelajaran menyampiakan pesan, memberi informasi yang tepat kepada pengguna tentang penemuannya dan kesimpulan hasil pengumpulan informasi, analisis dan tafsiran informasi evaluasi program (Tayibnapis, 2008:136).

\section{Tindak Lanjut}

Tindak lanjut merupakan langkah-langkah yang harus diambil oleh pendidik atau institusi setelah laporan evaluasi diserahkan (Agensyah, Darwanis, \& Syahputra., 2017:4). Tindak lanjut sebagai salah satu hasil akhir pengawasan adalah penting karena tanpa tindak lanjut aktifitas pengawasan menjadi tidak efektif (Agensyah, Darwanis, \& Syahputra., 2017:3).

Sedangkan pengawasan ekternal merupakan suatu kegiatan untuk mencocokkan apakah kegiatan pelaksanaan pembelajaran sesuai dengan rencana yang telah ditetapkan dalam mencapai tujuan dari institusi pendidikan dan suatu proses dimana pimpinan ingin mengetahui apakah hasil pelaksanaan pekerjaan yang dilakukan oleh dosen sesuai dengan rencana, perintah, tujuan, atau kebijaksanaan yang telah ditentukan dan kemudian mengarahkan kembali ke jalur tujuan yang benar bila melenceng dari tujuan yang telah direncakan (Glendoh, 2000:46). Pengawasan ekternal proses pembelajaran dilakukan melalui kegiatan pemantauan, supervisi, evaluasi, serta tindak lanjut secara berkala dan berkelanjutan yang dilakukan oleh program studi dan P2M (Puspitasari, 2017:349).

Satya Widya: Jurnal Studi Agama

Volume 2 Nomor 1 Juni 2019 


\section{Pemantauan}

Pemantauan adalah proses pengumpulan dan analisis informasi kinerja pendidik terhadap proses pembelajaran berdasarkan indikator yang ditetapkan secara sistematis dan kontinu sehingga dapat dilakukan tindakan koreksi untuk penyempurnaan kegiatan (Widiastuti \& Susanto, 2014:196).

\section{Supervisi}

Supervisi merupakan bimbingan profesional bagi pendidik dalam mengembangkan proses pembelajaran, termasuk segala unsur penunjangnya (Pidarta, 2009:2). Bimbingan profesional yang dimaksut adalah segala usaha yang memberikan kesempatan bagi pendidik untuk berkembang secara profesional, sehingga pendidik lebih maju lagi dalam melaksanakan tugas pokoknya, yaitu memperbaiki dan meningkatkan proses belajar mahasiswa (Tim Dosen Administrasi Pendidikan UPI, 2012:313).

\section{Evaluasi Kinerja}

Evaluasi kinerja adalah suatu kegiatan mengukur/menilai pelaksanaan pekerjaan untuk menetapkan sukses atau gagalnya seorang pekerja dalam melaksanakan tugas dan tanggung jawab dibidang kerjanya masing-masing (Widarsih \& Faraz, 2016:180), dengan membandingkan standar kinerja sesuai kriteria yang telah ditetapkan terlebih dahulu dan hasil dari evaluasi dapat digunakan sebagai masukan untuk melakukan kegiatan yang lebih baik pada masa akan datang (Kartomo \& Slameto, 2016:222).

\section{Pelaporan}

Pelaporan merupakan catatan hasil dari monitoring dan evaluasi program atau kegiatan dalam bentuk kualitatif atau kuantitif berdasarkan pada hasil pengamatan dan evaluasi yang dilakukan dengan menggunakan instrumen yang dibuat (Triwiyanto, 2015:68), untuk kepentingan tindak lanjut pengembangan keprofesionalan pendidikan secara berkelanjutan (Puspitasari, 2017:4).

\section{Tindak Lanjut}

Tindak lanjut hasil pegawasan dilakukan dalam bentuk: (a) Penguatan dan penghargaan kepada pendidik yang menunjukkan kinerja yang memenuhi atau melampaui standar. (b) Pemberian kesempatan kepada pendidik untuk mengikuti program pengembangan keprofesionalan berkelanjutan (Puspitasari, 2017:349).

\section{Simpulan}


Berdasarkan hasil penelitian, implementasi manajemen pembelajaran saintifik yang dilaksanakan di IAHN-TP palangka Raya terdiri dari beberapa tahapan, antara lain: Perencanaan pembelajaran; Pendidik merumuskan RPS; menyusun perangkat pembelajaran berupa buku pedoman pembelajaran yang digunakan oleh pendidik dan buku pedoman yang digunakan mahasiswa dan kontrak perkuliahan; menyerahkan RPS dan perangkat pembelajaran berupa pedoman dan kontrak perkuliahan kepada program studi untuk dievaluasi apakah sudah sesuai dengan kurikulum dan silabus yang ada. Pelaksanaan pembelajaran; Tahap awal, terdiri dari pendidik memberi salam dan mengajak mahasiswa berdoa; Pendidik mengabsen mahasiswa, serta menanyakan keadaannya; Pendidik akan menyampaikan isi dari silabus, RPS dan kontrak perkuliahan dengan tujuan agar mahasiswa dapat memahami tujuan dari proses pembelajaran, pendekatan, metode dan penilaian pembelajaran selama satu semester yang akan dijalani; dosen memberikan gambaran tentang pentingnya memahami materi yang akan dibahas sekaligus memberikan gambaran secara umum materi yang akan dipelajari, serta menyampaikan capian pembelajaran yang ingin dicapai; dosen memberikan apersepsi untuk mendorong rasa ingin tahu dan berpikir kritis, dengan tanya jawab, mahasiswa diajak mengingat kembali tentang gambaran materi secara umum berdasarkan tugas mandiri yang telah diberikan; dosen membentuk kelompok belajar; dosen memberikan tugas mandiri sebelum pembelajaran dimulai dengan tema materi pertemuan selanjutnya. Tahap Inti, terdiri dari Mengamati; menanya; mengumpulkan informasi; mengolah informasi; mengkomunikasikan. Tahap Penutup, terdiri dari pendidik bersama mahasiswa menyimpulkan hasil pembahasan dan pendidik memberikan penguatan; Pendidik dan mahasiswa melakukan refleksi terhadap hasil diskusi; Pendidik memberikan tugas mandiri berstruktur untuk pertemuan berikutnya; Diakhiri dengan doa. Pengawasan pembelajaran; pengawasan proses pembelajaran dilakukan melalui kegiatan pemantauan, supervisi, evaluasi, pelaporan, serta tindak lanjut secara berkala dan berkelanjutan.

\section{Daftar Pustaka}

Abidin, Y. (2016). Desain sistem pembelajaran dalam konteks kurikulum 2013. Bandung: Rafika Aditama.

Agensyah, A., Darwanis, \& Syahputra., M. (2017). Pengaruh efektivitas pengawasan, frekuensi pemeriksaan dan tindak lanjut temuan inspektorat terhadap kinerja satuan kerja pemerintah Aceh pada provinsi Aceh. Jurnal akuntasi pascasarjana universitas Syiah Kuala, 6(1), 1-10. 
Andayani. (2015). Problema dan aksioma: dalam metodologi pembelajaran bahasa indonesia. Yogyakarta: publisher.

Asmarawati, E., Riyadi, \& Sujadi, I. (2016). Proses integrasi sikap sosial dan spiritual dalam pembelajaran matematika pada siswa kelas VII SMP negeri di kecamatan Purwodadi. Jurnal elektronik pembelajaran matematika, 4(1), 58-69.

Atsnan, M. F., \& Gazali, R. Y. (2013). Penerapan pendekatan scientific dalam pembelajaran matematika SMP kelas VII materi bilangan ( pecahan ). In proseding seminar nasional matematika dan pendidikan matematika fmipa UNY (pp. 978-979). Yogyakarta.

Awaludin, Mallo, B., \& Lefrida, R. (2016). Penerapan model pembelajaran kooperatif tipe investigasi kelompok untuk meningkatkan hasil belajar siswa pada materi sifat-sifat penjumlahan dan pengurangan bilangan bulat di kelas VII MTS putri aisyiyah palu. Aksioma jurnal pendidikan matematika, 5(3), 74-85.

Barlian, I. (2013). Begitu pentingkah strategi belajar mengajar bagi guru? Ikbal barlian. Jurnal forum sosial, vi(1), 241-246.

Dahar, R. W. (2011). Teori-teori belajar dan pembelajaran. Jakarta: airlangga.

Glendoh, S. H. (2000). Fungsi pengawasan dalam penyelenggaraan manajemen korporasi. Jurnal manajemen dan kewirausahaan, 2(1), 43-56.

Gora, Winastwan, \& Sunarto. (2010). Pakematik strategi pembelajaran inovatif berbasis TIK. Jakarta: elex media komputindo.

Gunawan, I., \& Palupi, A. R. (2012). Taksonomi bloom - revisi ranah kognitif: kerangka landasan untuk pembelajaran, pengajaran, dan penilaian. Premiere educandum : jurnal pendidikan dasar dan pembelajaran, 2(2), 16-40.

Hadi, S. N., \& Noor, A. J. (2013). Keefektifan kelompok belajar siswa berdasarkan sosiometri dalam menyelesaikan soal cerita matematika di SMP. Edu-mat jurnal pendidikan matematika, 1(1), 60-67.

Hamalik, O. (1995). Kurikulum dan pembelajaran. Jakarta: bumi aksara.

Hosnan. (2014). Pendekatan saintifik dan kontekstual dalam pembelajaran abad 21. Bogor: gahlia indonesia.

Husman, H. (2008). Manajemen: teori praktik \& riset pendidikan, edisi kedua. Jakarta: bumi aksara.

Ikhwan, A. (2016). Manajemen perencanaan pendidikan islam. Edukasi, 4(1), 128-155.

Isnaniah. (2017). Peningkatkan kreativitas dan kemandirian belajar mahasiswa melalui model pembelajaran berbasis proyek pada perkuliahan media pembelajaran matematika. Suska 
journal of mathematics education, 3(2), 83-91.

Kartiani, B. S. (2015). Pengaruh metode pembelajaran dan motivasi belajar terhadap hasil belajar siswa pada mata pelajaran ips kelas V kabupaten Lombok barat NTB. Jurnal pendidikan dasar, 6(2), 212-221.

Kartomo, A. I., \& slameto. (2016). Evaluasi kinerja guru bersertifikasi. FKIP universitas kristen Satya Wacana, 3(2), 219-229.

Kosasih, E. (2014). Strategi belajar dan pembelajaran (implementasi kurikulum 2013). Bandung: yrama widya.

Kurniadin, D., \& Machali, I. (2012). Manajemen pendidikan konsep \& prinsip pengelolaan pendidikan. Jogjakarta: ar-ruzz media.

Lukum, A. (2015). Evaluasi program pembelajaran ipa smp menggunakan model countenance stake. Jurnal penelitian dan evaluasi pendidikan, 19(1), 25-37.

Lutfiyanti, T. (2013). Penerapan bimbingan kelompok belajar untuk meningkatkan kemampuan interaksi sosial siswa kelas XI IPA C SMA Negeri 2 Tuban. Bk unesa, 4(1), $338-347$.

Majid, A. (2005). Perencanaan pembelajaran: mengembangkan standar kompetensi guru. Bandung: remaja rosdakarya.

Manullang, M. (2014). Manajemen pembelajaran matematika. Jurnal pendidikan dan pembelajaran, 21(2), 208-214.

Mukhtar, H., \& iskandar. (2013). Orientasi baru supervisi pendidikan. Bandung: Referensi.

Mulyana, A., Adnan, H., Indriatmoko, Y., Priyono, A., \& Moeliono, M. (2008). Belajar sambil mengajar : menghadapi perubahan sosial untuk pengelolaan sumber daya alam. Bogor: cifor.

Mulyono, \& Yumari. (2017). Strategi monitoring \& evaluasi pelaksanaan anggaran. Yogyakarta: deepublish.

Novalita, R. (2014). Pengaruh perencanaan pembelajaran terhadap pelaksanaan pembelajaran (suatu penelitian terhadap mahasiswa pplk program studi pendidikan geografi fkip universitas almuslim). Lentera, 14(2), 56-61.

Palupi, E. W., Yuwono, I., \& Muksar, M. (2017). Pengembangan permainan kotak barisan yang digunakan pada kegiatan apersepsi materi barisan dan deret untuk meningkatkan motivasi siswa kelas x sma. Jurnal kajian pembelajaran matematika, 1(1), 10-16.

Pidarta, M. (2009). Supervisi pendidikan kontekstual. Jakarta: rineka cipta.

Purnomo, E., \& Munadi, S. (2005). Evaluasi hasil belajar dalam implementasi kurikulum 
berbasis kompetensi di sekolah menengah kejuruan. Cakrawala pendidikan, 24(2), 259272.

Puspitasari, H. (2017). Standar proses pembelajaran sebagai sistem penjaminan mutu internal di sekolah. Muslim heritage, 1(2), 339-368.

Putra, N. (2015). Penilaian autentik mata pelajaran pendidikan agama. Jurnal al-fikrah, 3(2).

Rayuni, D. (2010). Manajemen pembelajaran di madrasah aliyah negeri (MAN) 3 Palembang. Ta'dib, xv(1).

Rukayah, \& Ismanto, B. (2016). Evaluasi manajemen berbasis sekolah di sekolah dasar negeri kabupaten semarang. Kelola jurnal manajemen pendidikan UKSW, 3(2), 178191.

Rusman. (2017). Belajar \& pembelajaran berorientasi standar proses pendidikan. Jakarta: kencana.

S, M., Usman, N., \& Niswanto. (2017). Evektifitas pelaksanaan tugas pengawas dalam meningkatkan mutu pendidikan pada sekolah dasar lingkungan uptd suku i disdikpora kota banda aceh. In prosiding seminar nasional pascasarjana (SNP) unsyiah (pp. 154159). Banda aceh: unsyiah.

Sagala, S. (2011). Manajemen strategik dalam peningkatan mutu pendidikan. Bandung: alfabeta.

Saifudin. (2014). Pengelolaan pembelajaran teoritis dan praktis. Yogyakarta: deepublish.

Samiudin. (2016). Peran metode untuk mencapai tujuan pembelajaran. Jurnal studi islam, 11(2), 94-97.

Sari, I. M. (2015). Penggunaan model listening team sebagai sarana meningkatkan kemampuan bertanya pada pembelajaran ipa siswa kelas x smk yp 17-2 madiun. Jurnal florea, 2(1), 23-28.

Setiawan, D. (2017). Pendekatan saintifik dan penilaian autentik untuk meningkatkan mutu pembelajaran pendidikan agama islam. Al-asasiyya: journal of basic education, 1(2), 34-46.

Sidek, E. A. R., \& Yunus, M. M. (2012). Students' experiences on using blog as learning journals. Procedia - social and behavioral sciences, 67(november 2011), 135-143.

Soemohadiwidjojo, A. T. (2014). Mudah menyusun SOP. Jakarta: penebar plus.

Suardi, M. (2015). Belajar \& pembelajaran. Yogyakarta: deepublish.

Suhartati. (2016). Penerapan pendekatan saintifik pada materi relasi dan fungsi di kelas $\mathrm{x}$ man 3 banda aceh. Jurnal peluang, 4(april). 
Sulistyowati, N. W. (2016). Implementasi small group discussion dan collaborative learning untuk meningkatkan prestasi belajar mahasiswa program studi pendidikan akuntansi ikip pgri madiun. Assets : jurnal akuntansi dan pendidikan, 5(44), 173-190.

Sunaryo, Y. (2014). Model pembelajaran berbasis masalah untuk meningkatkan kemampuan berpikir kritis dan kreatif matematik siswa sma di kota tasikmalaya. Jurnal pendidikan dan keguruan, 1(2), 41-51.

Suprihatin, S. (2015). Upaya guru dalam meningkatkan motivasi belajar siswa. Promosi jurnal pendidikan ekonomi um metro, 3(1), 73-82.

Suryapermana, N. (2017). Manajemen perencanaan pembelajaran. Tarbawi, 3(2), 183-193.

Sutrisno, \& Suyadi. (2016). Desain kurikulum perguruan tinggi, mengacu KKNI. Bandung: pt remaja rosdakarya.

Suyanto, \& Jihad, A. (2013). Menjadi guru profesional. Jakarta: esensi erlangga group.

Tayibnapis, F. Y. (2008). Evaluasi program dan instrumen evaluasi untuk program pendidikan dan penelitian. Jakarta: rineka cipta.

Terry, G. R. (2012). Asas - asas manajemen edisi kedelapan. Terjemahan winardi. Bandung: pt alumni.

Tim dosen administrasi pendidikan UPI. (2012). Manajemen pendidikan. (riduwan, ed.). Bandung: alfabeta.

Triwiyanto, T. (2015). Pelaksanaan monitoring, evaluasi, dan pelaporan untuk penilaian kinerja manajerial kepala sekolah. Cakrawala pendidikan, XXXIV(1), 67-77.

Widarsih, R., \& Faraz, N. J. (2016). Evaluasi kinerja guru ips smp berdasarkan standar kompetensi guru di kabupaten kebumen. Harmoni sosial: jurnal pendidikan IPS, 3(2), $177-187$.

Widiastuti, N. I., \& Susanto, R. (2014). Kajian sistem monitoring dokumen akreditasi teknik informatika unikom. Majalah ilmiah unikom, 12(2), 195-202.

Widiawati, P. D., Nurani, A. S., \& Patriasih, R. (2015). Penerapan pendekatan saintifik learning pada mata pelajaran pengolahan makanan kontinental di smkn 2 baleendah. Media pendidikan, gizi dan kuliner, 4(2), 39-48.

Widodo, J. (2007). Supervisi guru mata pelajaran ekonomi di indonesia: antara teori dan realita. Jurnal pendidikan ekonomi, 2(2), 291-313.

Widyanto, I. P., Slamet, A., \& Prihatin, T. (2018). The Utilization of Whatsapp Application on Scientific-Based Learning Management in Higher Education Institutions. In Advances in Social Science, Education and Humanities Research (ASSEHR) (Vol. 247, 
pp. 241-245). Atlantis Press.

Zuhri, M. N. C. (2013). Studi tentang efektivitas tadarus al-qur`an dalam pembinaan akhlak di smpn 8 yogyakarta. Cendekia, 11(1), 113-129. 